\title{
Effect of Entrepreneurship Education Program to Attitudes Toward Starting a Business, Entrepreneurial Desirability, Competence, and Intention
}

\author{
Dr. ROMMEL A. AVILLANOZA \\ Assistant Professor, Occidental Mindoro State College. \\ Email: mel.avillanoza@gmail.com \\ Ms. MARILOU D. DOMINGO \\ Instuctor, Occidental Mindoro State College. \\ Email: domingomalou082@gmail.com
}

\begin{abstract}
This study determines the effect of entrepreneurship education on attitudes toward starting a business, entrepreneurial desirability, competence, and intention. Experimental research using pre-test and post-test design was used. The authors have set-up a mini-store inside the school campus and taught the students the basics of business operations for four months. The students were asked to evaluate themselves before and after the program about their perceptions of attitudes toward starting a business, entrepreneurial desirability, competence, and intention. The findings show that entrepreneurship education program has a significant influence on students' attitudes toward starting a business and entrepreneurial intention.
\end{abstract}

Keywords: Entrepreneurship Training; Theory of Planned Behavior, Entrepreneurial Intention, Entrepreneurial Skills, Entrepreneurs.

\section{Introduction}

Entrepreneurship serves as an important vehicle for economic and social prosperity. It plays a significant role in the development in many countries by promoting technological innovations, snowballing economic growth and efficiency, and ease unemployment by creating new jobs (Acs, et al., 2009; Williams \& Huggins, 2013; Shane, \& Venkataraman, 2000). Entrepreneurship helps social prosperity by establishing social relationships between individuals and communities and improving the quality of human resources (Kirkwood \& Walton, 2010; Mitra et al., 2011).

The overwhelming impact of entrepreneurship becomes the buzz word these days not only among the policymakers as well as in the academic community around the world (Astebro \& Bazzazian, 2011; Kuratko, 2005; Wright, et al., 2007). Policymakers and the academe have sought entrepreneurship promotion to address unemployment in the hope to unlock the latent entrepreneurial talent of the population that would create positive economic and social benefits to society.

In support of the entrepreneurship endeavor of the country, the researchers' institution received funding from the Commission of Higher Education (CHED) under the Institutional Development and Innovation Grant of K to 12 Transition Program for establishing a student business center. The student business center aims to equip students with the knowledge and skills in running a business by providing them with an onthe-job environment that will help them grow as an individual. The program enables the beneficiaries to enhance their knowledge and skills in accounting, operations management, marketing, financial management, and customer relation and eventually develop their attitudes toward entrepreneurship. 


\section{Research Questions}

The study aims to determine the effect of the entrepreneurship education program on attitude towards starting a business, entrepreneurial desirability, competence, and intention. Specifically, the study sought to answer the following questions:

- What is the extent of students' attitude towards starting a business, entrepreneurial desirability, competence, and intention before and after the entrepreneurship education program?

- Is there a significant difference in the extent of students' attitudes toward starting a business, entrepreneurial desirability, competence, and intention after the entrepreneurship education program?

\section{Literature Review}

The academic community recognized the importance of entrepreneurship as evident by conducting different studies and offering entrepreneurship education programs (Viana, Carvalho, Candido, 2019; Saleem \& Anwar, 2018; Oosterbeek, Praag, Ijsselstein, 2010; Sharaf, El-gharbawy, Ragheb, 2018). They believed that entrepreneurship is an effective and efficient strategy to increase the number and quality of entrepreneurs in the assumption that entrepreneurial intentions and skills can be imparted and learned (Matlay \& Carey, 2007; Clark, Davis, \& Harnish, 1984; Gorman, Hanlon \& King,1997; Peterman and Kennedy, 2003; Pittaway and Cope, 2007). The study of Yaghoubi-Farani, Karimi, and Motaghed, (2017) showed that entrepreneurial education is needed to improve students' skills and knowledge and enhance their entrepreneurial intention.

Because of this, strengthening the entrepreneurial mindsets of younger generations might be considered vital for the successful economic and social evolvement (Širola, 2020). Entrepreneurship education program implemented by universities and colleges often involves a selection of complementary business activities which involves planning, funding, implementation and evaluation with the purpose to determine its effect to entrepreneurial intention, competencies, attitudes (Souitaris, Zerbinati, and Al-Laham, 2007; Çera, et al., 2020; Saleem \& Anwar, 2018; Zelienková, \& Kozarova, 2019; Rodrigues, et al., 2012.

Entrepreneurship education programs that combine training with finance have more impact on raising selfemployment through start-ups as well as enhancing business performance and practices (Cho \& Honorati, 2013; de Mel, Mckenzie, \& Woodruff, 2012). But the question as to whether entrepreneurship education can make a change to business outcomes or even has an effect on entrepreneurial intention has always been open to question and at present suffers from a lack of empirical testing (Cowling, 2009; Byabashaija and Katono, 2011).

\section{Methodology}

The study is an experimental design with pre-test and post-test. The sample was composed of fifteen (15) college freshmen students taking accounting program. The participants were selected according to specified criteria which include but are not limited to age, gender, work experience, and family background. The entrepreneurial education program includes planning, funding, setting up of mini-store inside the school campus, initial procurement of merchandise, training on basic business operations, accounting and reporting, and profit-sharing. The students were also taught all stages in the trading business, how to create and develop products, and provided an opportunity to interact with different people on the campus.

To measure entrepreneurial desirability and intention (Inna \& Anne, 2014) and other constructs, the students were surveyed before the start of the program and four (4) months thereafter. Mean, standard deviation, Levene's test for equality of variance, and t-test were used as statistical treatment. 


\section{Results}

Descriptive statistics of the summated scales and indicators were presented as shown in Table 1 (attitude towards starting a business), Table 2 (entrepreneurial desirability), Table 3 (entrepreneurial skills), and Table 4 (summated scales).

Table 1 shows the result of students' responses in their attitude towards starting a business using a fivepoint Likert scale. The table indicates that the mean score of all constructs have increased in the two periods while its data dispersions have narrowed. This can mean that the students' attitude toward starting a business became more similar to one another and the entrepreneurial training program has also effected their attitude toward starting a business.

Table 1. Descriptive statistics of attitude towards starting a business.

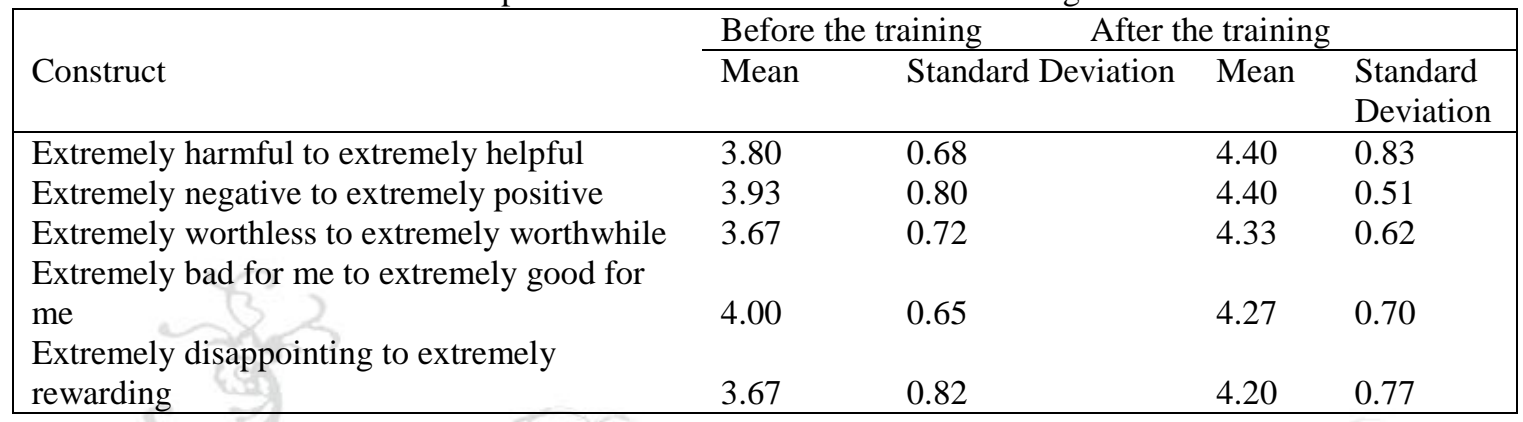

Table 2 shows that the means have risen in the two periods. Except for constructs "opportunities to meet interesting people" and "entrepreneurship suits my character", all constructs have increased in the means and data dispersions which can mean that the entrepreneurial training program has an effect on the students' entrepreneurial desirability and made them more different from each other.

Table 2. Descriptive statistics of entrepreneurial desirability

\begin{tabular}{|llcccc|}
\hline & \multicolumn{1}{c}{ Construct } & \multicolumn{2}{c|}{ Before the training } & \multicolumn{2}{c|}{ After the training } \\
\cline { 3 - 6 } & Mean & $\begin{array}{c}\text { Standard } \\
\text { Deviation }\end{array}$ & Mean & $\begin{array}{c}\text { Standard } \\
\text { Deviation }\end{array}$ \\
\hline 1. & The liberty of being one's own 'boss' & 3.33 & 1.18 & 3.87 & 1.25 \\
2. & The liberty in choosing one's tasks and duties & 3.07 & 1.03 & 3.67 & 1.35 \\
3. & The liberty of choosing one's working hours & 3.33 & 0.90 & 3.73 & 1.16 \\
4. & Interesting tasks and duties, and their variety & 3.47 & 1.25 & 3.80 & 1.32 \\
5. & Result-based income & 3.67 & 0.98 & 3.67 & 1.45 \\
6. & Opportunities to meet interesting people & 3.73 & 1.33 & 3.93 & 1.28 \\
7. & Entrepreneurship suits my character & 3.13 & 1.16 & 3.40 & 1.06 \\
8. & Entrepreneurship unifies the entire family & 2.80 & 0.94 & 3.20 & 1.42 \\
\hline
\end{tabular}

The means of entrepreneurial competence of the students have risen while its data dispersions have widened in the two periods as shown in Table 3. This can mean that the entrepreneurial training program has an effect on the entrepreneurial competence of the students. Among the constructs of entrepreneurial competence, the mean of construct "negotiation skills" has increased the most with its mean difference of 0.60 while construct "skills of accounting and financial management of the enterprise" became more dispersed than the others. This can mean that the entrepreneurial training programs have effected more on students' negotiation and financial management skills. 
Table 3. Descriptive statistics of entrepreneurial competence

\begin{tabular}{|c|c|c|c|c|}
\hline \multirow[b]{2}{*}{ Construct } & \multicolumn{2}{|c|}{ Before the training } & \multicolumn{2}{|c|}{ After the training } \\
\hline & Mean & $\begin{array}{l}\text { Standard } \\
\text { Deviation }\end{array}$ & Mean & $\begin{array}{l}\text { Standard } \\
\text { Deviation }\end{array}$ \\
\hline 1. Marketing skills & 2.87 & 0.83 & 3.07 & 0.88 \\
\hline 2. Customer relation & 3.33 & 0.98 & 3.40 & 1.40 \\
\hline 3. Business planning & 3.13 & 0.83 & 3.47 & 1.06 \\
\hline 4. Basic business operations management & 3.20 & 0.94 & 3.40 & 1.18 \\
\hline $\begin{array}{l}\text { 5. Practical information about starting a } \\
\text { business. }\end{array}$ & 3.33 & 1.05 & 3.73 & 1.16 \\
\hline 6. Business opportunity recognition/evaluation & 3.00 & 0.76 & 3.40 & 1.06 \\
\hline 7. Business idea generation/idea development & 2.93 & 0.96 & 3.47 & 1.19 \\
\hline 8. Negotiation skills & 2.73 & 0.88 & 3.33 & 1.23 \\
\hline $\begin{array}{l}\text { 9. Skills of accounting and financial } \\
\text { management of the enterprise }\end{array}$ & 3.00 & 0.65 & 3.47 & 1.13 \\
\hline 10. Teamwork & 3.47 & 1.06 & 3.87 & 1.30 \\
\hline 11. Leadership & 3.20 & 1.15 & 3.60 & 1.30 \\
\hline 12. Skills of commercialization of innovations & 3.40 & 1.18 & 3.40 & 1.18 \\
\hline
\end{tabular}

To determine the entrepreneurial intention of the students, two (2) constructs were used as presented in Table 4. Although there is an increase in the means of the two constructs in the two periods, the data dispersion has no significant changes after the training program

Table 4. Descriptive statistics of entrepreneurial intention

\begin{tabular}{|c|c|c|c|c|}
\hline \multirow{2}{*}{ Wo Construct } & \multicolumn{2}{|c|}{ Before the training } & \multicolumn{2}{|c|}{ After the training } \\
\hline & Mean & $\begin{array}{c}\text { Standard } \\
\text { Deviation }\end{array}$ & Mean & $\begin{array}{l}\text { Standard } \\
\text { Deviation }\end{array}$ \\
\hline $\begin{array}{l}\text { 1. I will try to start my own business within the } \\
\text { first } 5 \text { years after finishing my studies. } \\
\text { 2. I am determined to create a business venture } \\
\text { in the future. }\end{array}$ & 3.93 & 0.70 & $\begin{array}{l}4.60 \\
4.47\end{array}$ & $\begin{array}{l}0.74 \\
0.74\end{array}$ \\
\hline
\end{tabular}

In summary, Table 5 shows that the means of entrepreneurial desirability, entrepreneurial skills, attitude towards starting a business, and entrepreneurial intention have increased after the entrepreneurial training program. Although the data dispersion of attitude towards starting a business and entrepreneurial intention is similar in the periods, the data dispersion of entrepreneurial desirability and entrepreneurial skills have widened.

Table 5. Summative statistics

\begin{tabular}{|lcccc|}
\hline & \multicolumn{2}{c|}{ Before the training } & After the training \\
\cline { 2 - 5 } \multicolumn{1}{c}{ Construct } & Mean & Standard Deviation & Mean & $\begin{array}{c}\text { Standard } \\
\text { Deviation }\end{array}$ \\
\hline Attitude toward starting a business & 3.81 & 0.61 & 4.32 & 0.57 \\
Entrepreneurial desirability & 3.32 & 0.77 & 3.66 & 1.13 \\
Entrepreneurial competence & 3.11 & 0.73 & 3.47 & 1.05 \\
Entrepreneurial intention & 3.80 & 0.75 & 4.53 & 0.72 \\
\hline
\end{tabular}

Considering a confidence level of 95\%, Table 6 shows that there is a homogeneity of variances among the constructs. This means that the students are similar regarding entrepreneurial desirability, entrepreneurial skills, attitude towards starting a business, and entrepreneurial intention after undergoing the training program. A possible explanation is that the students are all taking accounting courses; hence, they are more inclined in being engaged in business whether employment or entrepreneurship. 
Table 6 shows that there is a significant difference in the means of attitude towards starting a business and entrepreneurial intention before and after the training program. This is consistent with the results in Tables 1 and 2 which indicates an increase in the means of entrepreneurial desirability and entrepreneurial skills. The training program made the students more skillful and kindled their desire towards entrepreneurship, hence, their attitude towards starting a business and entrepreneurial intention significantly increased.

Table 6. Test for equality of variance and means.

\begin{tabular}{|c|c|c|c|c|c|c|c|c|}
\hline \multirow[b]{2}{*}{ Construct } & \multicolumn{3}{|c|}{ Mean } & \multicolumn{2}{|c|}{$\begin{array}{c}\text { Levene's Test for } \\
\text { Equality of } \\
\text { Variances } \\
\end{array}$} & \multicolumn{3}{|c|}{ t-test for equality of means } \\
\hline & $\begin{array}{c}\text { Before } \\
\text { the } \\
\text { training }\end{array}$ & $\begin{array}{c}\text { After } \\
\text { the } \\
\text { training }\end{array}$ & $\begin{array}{c}\text { Mean } \\
\text { Difference }\end{array}$ & $\mathrm{F}$ & Sig. & $\mathrm{t}$ & df & $\begin{array}{c}\text { Sig. } \\
\text { (2-tailed) }\end{array}$ \\
\hline Desirability & 3.32 & 3.68 & .341 & 2.089 & .159 & -.971 & 28 & .341 \\
\hline Skills & 3.11 & 3.47 & .361 & 3.974 & .056 & -1.092 & 28 & .285 \\
\hline Attitude & 3.81 & 4.32 & .507 & .008 & .931 & -2.348 & 28 & .026 \\
\hline Intention & 3.80 & 4.53 & .733 & .125 & .727 & -2.732 & 28 & .011 \\
\hline
\end{tabular}

\section{Discussion}

Based on the aforementioned results, the entrepreneurship education program exhibited a positive response from the students as manifested by a significant increase in their attitude toward starting a business and entrepreneurial intention (Peterman and Kennedy, 2003; Fayolle, Gailly, Lassas-Clerc, 2006); Raposo, et al., 2008). The study also affirms that students in public universities are highly homogenous (Noorkartina et al., 2015).

The entrepreneurship education program implemented by the researchers helps the students to understand more the importance of having your own business. It helps the students to understand and experience the motivations in doing business. The program provides them to have a chance to meet different people, felt the liberty of being a 'boss', and have an interesting variety of tasks and duties. According to Bakotic and Kruzic, (2010), the students after being involved in numerous activities during the programs are all participative and eager to learn as they are willing to put their effort into all entrepreneurship activities.

Entrepreneurship education as a vital component of business schools' curriculum is believed to be an effective and efficient method to increase the number of entrepreneurs and improve the quality of entrepreneurship ( Matlay \& Carey, (2007). According to Rae (2010) education is essential in understanding entrepreneurship, developing entrepreneurial capabilities, and contributing to entrepreneurial identities and cultures at the individual, collective, and social levels. Furthermore, entrepreneurship education is also believed to contribute to the development and improvement of essential entrepreneurial skills like innovation skills, negotiation skills, financial management skills, and teamwork (Inna \& Anne, 2014; Heinonen, 2007; Chia, 1996). Entrepreneurial education empowers the individual with analytical skills and knowledge of the entrepreneurial process that improves the entrepreneurial opportunities assessment (McMullen \& Shepherd, 2006).

While the study showed that the entrepreneurship education program has no effect on entrepreneurship competencies of students undertaking "mini-company" (Oosterbeek et al., 2010). The results can be possibly related to the fact that students know some extent in the indicators of competency. The insignificant increases in the competencies cannot be considered as a failure of the program but rather it gives an opportunity to enhance the program with more rigorous activities and guidance from real entrepreneurs. 
Furthermore, the assessment of the program showed a significant increase in the students' attitude toward starting a business after its implementation. Studies have shown that positive entrepreneurial attitude and desirability influence entrepreneurial intention while entrepreneurial intentions determine the likelihood of starting a business (Misoska, Dimitrova \& Mrsik, 2016; (Păunescu, Popescu \& Duennweber, 2018). The effect of the program on entrepreneurial traits and intentions are good predictors of entrepreneurial orientation (Park and $\mathrm{Ku}, 2008$ )

Studies have shown that entrepreneurship education programs have a positive impact on entrepreneurial desirability, competence, attitude toward starting a business, and entrepreneurial intention. However, it is still unclear whether the entrepreneurial education programs have an impact on the quality of entrepreneurial graduates or it will enable the graduates to establish their businesses. According to Nabi et al. (2010), this kind of research tells us very little about the changes brought by higher education to graduates' attitudes towards entrepreneurship and the transition to entrepreneur. However, it is still necessary to reflect on the relevance of what educators are teaching in the classroom, and more particularly, if start-up activities are effectively reflected in entrepreneurship course content and delivery (Edelman, Manalova \& Brush, 2008).

Based on the result of the study, experiential entrepreneurial education gave a positive impact on the students' attitude towards starting a business, and entrepreneurial intention. Thus, the authors recommended that universities should include entrepreneurship courses in all business programs and integrate entrepreneurial spirits into the educational outcomes of other academic programs(Srirejeki \& Faturokhman, 2020). Continuance of "mini-store" operations is also recommended for the students to gain experience in entrepreneurship which is effective for the development of entrepreneurial competencies, foremost development of entrepreneurial knowledge (Zelienková \& Kožárová, 2019).

Supports system for graduate startups could be established by the school in partnership with government organizations (GOs), non-government organizations (NGOs), and private companies. The support system should provide the students with an avenue where they can ask for assistance such as access to capital, market information, consultancy, and access to any government support. This system may also organize entrepreneurial activities such as business idea competitions and trade fairs.

The university may create a business center where the products of the faculty and students may be exhibited and sold. The business center may act as a training ground and business incubator for aspiring entrepreneurs. This can expose students to real business experience which can open their minds about the risk and opportunities of doing business and the peculiarities of each type. The business experiences the students may gain in the business will give them ideas on what business they may start in the future.

\section{Conclusion}

The entrepreneurial education program implemented by the researchers which consist of establishing a "mini-store" inside the school campus and profit-sharing agreement has a significant effect on the attitude toward starting a business and entrepreneurial intention of the students. The study also found out the students are homogenous and the entrepreneurship education program has no significant effect on entrepreneurial desirability and competence.

\section{Acknowledgement}

The authors would like to acknowledge the Commission of Higher Education of the Philippines through the Institutional Development and Innovation Grants (IDIG) which is part of CHED K to 12 Transition

Program for the funding of the project. 


\section{References}

Acs, Z. J., Braunerhjelm, P., Audretsch, D. B., \& Carlsson, B. (2009). The knowledge spillover theory of entrepreneurship. Small Business Economics, 32(1), 15-30. https://doi.org/10.1007/s11187-008-9157-3

Astebro, T. \& Bazzazian, N. (2011). Universities, Entrepreneurship and Local Economic Development. Handbook of Research on Entrepreneurship and Regional Development.

Bakotic, D. and Kruzic, D. (2010). Students' perceptions and intentions towards entrepreneurship: the empirical findings from Croatia, The Business Review, 14(2): 209-215.

Byabashaija, W. \& Katono, I. (2011). "The Impact of college entrepreneurial education on entrepreneurial attitudes and intention to start a business in Uganda", Journal of Developmental Entrepreneurship, Vol. 16 No. 1, pp. 127-144

Çera, Gentjan, Çera, \& Edmond (2020). Intention to start a business and entrepreneurship education programme: a pre- and post-programme research design. Journal of Enterprising Communities: People and Places in the Global Economy. ahead-of-print. 10.1108/JEC-05-2020-0095.

Chia, R. (1996), Teaching paradigm shifting in management education: university business schools and the entrepreneurial imagination, Journal of Management Studies, 33 (4), p. 40

Cho, Y., \& Honorati, M. (2013). Entrepreneurship Programs in Developing Countries: A Meta Regression Analysis. Labour Economics, 28. https://doi.org/10.1016/j.labeco.2014.03.011

Clark. B. W., Davis. C. H., \& Harnish. V. C. (1984). Do Courses in Entrepreneurship Aid in New Venture Creation?. Journal of Small Business Management 22(2), 26-31.

Cowling, M. (2009). The Impact of Entrepreneurship Training and Small Business Experience on Future Entrepreneurial Activity in the UKInstitute for Employment Studies Working Paper: WP21

de Mel, S. \& Mckenzie, D. \& Woodruff, C. (2012). Business training and female enterprise start-up, growth, and dynamics: Experimental evidence from Sri Lanka. Journal of Development Economics. 106. 10.1016/j.jdeveco.2013.09.005.

Edelman, L.; Manolova, T. \& Brush, B. (2008). "Entrepreneurship education: correspondence between practices of nascent entrepreneurs and textbook prescriptions for success", Academy of Management Learning \& Education, 7(1), 56-70.

Fayolle A., Gailly B., \& Lassas-Clerc N. (2006). Assessing the impact of entrepreneurship education programme: a new methodology, Journal of European Industrial Training, 30 (8/9), pp. 701-720

Heinonen J., (2007). An entrepreneurial-directed approach to teaching corporate entrepreneurship at university level, Education + Training, 49 (4), pp. 310-324

Inna, K. \& Anne, G. (2014). GATE. Entrepreneurship Development in Gatchina District Evaluation Report. Aalto University publication series Business + Economy 2/2014. Retrieved from https://core.ac.uk/download/pdf/301130105.pdf

Kirkwood, J., \& Walton, S. (2010). What motivates ecopreneurs to start businesses? International Journal of Entrepreneurial Behaviour \& Research, 16, 204-228. https://doi.org/10.1108/13552551011042799

Kuratko, D. (2005). The Emergence of Entrepreneurship Education: Development, Trends, and Challenges. Entrepreneurship Theory and Practice, 29, 577-598. https://doi.org/10.1111/j.15406520.2005.00099.x

Matlay, H., \& Carey, C. (2007). Entrepreneurship Education in the UK: A Longitudinal Perspective. Journal of Small Business and Enterprise Development, 14, 252-263. https://doi.org/10.1108/14626000710746682

McMullen, J. S., \& Shepherd, D. A. (2006). Entrepreneurial action and the role of uncertainty in the theory of the entrepreneur. Academy of Management Review, 31(1), 132-152. doi:10.5465/amr.2006.19379628

Nabi, G., Holden, R., Walmsley, A., Holden, R. \& Walmsley, A. (2010). "Entrepreneurial intentions among students: towards a re-focused research agenda", Journal of Small Business and Enterprise Development, Vol. 17 No. 4, pp. 537-551.

Mitra, J., Abubakar, Y., \& Sagagi, M. (2011). Knowledge creation and human capital for development: the role of graduate entrepreneurship. Education + Training, 53, 462-479. https://doi.org/10.1108/00400911111147758 
Misoska, A., Dimitrova, M. \& Mrsik, J. (2016). Drivers of entrepreneurial intentions among business students in Macedonia, Economic Research-Ekonomska Istraživanja, 29:1, 1062-1074, DOI: 10.1080/1331677X.2016.1211956

Noorkartina, M., Hock-Eam, L., Norhafezah, Y., \& Jan-Jan, S. (2015). Estimating the effect of entrepreneur education on graduates' intention to be entrepreneurs. Education + Training, 57(8/9), 874-890. https://doi.org/10.1108/ET-03-2014-0030

Oosterbeek, H., van Praag, M., \& Ijsselstein, A. (2010). The impact of entrepreneurship education on entrepreneurship skills and motivation. European Economic Review, 54(3), 442-454. https://doi.org/10.1016/j.euroecorev.2009.08.002

Peterman, N. E., \& Kennedy, J. (2003). Enterprise Education: Influencing Students' Perceptions of Entrepreneurship. Entrepreneurship Theory and Practice 28(2), 129-144.

Păunescu, C., Popescu, M. C., \& Duennweber, M. (2018). Factors determining desirability of entrepreneurship in Romania. Sustainability (Switzerland), 10(11), 1-22. https://doi.org/10.3390/su10113893

Pittaway, L. \& Cope, J. (2007). Entrepreneurship education-A Systematic Review of The Evidence. International Small Business Journal 25(5), 479-510.

Rae, D. (2010). Universities and enterprise education: responding to the challenges of the new era, Journal of Small Business and Enterprise Development, 17(4): 591-606.

Raposo, M., Paço, A. \& Ferreira, J. (2008). "Entrepreneur's profile: a taxonomy of atributes and motivations of university students", Journal of Small Business and Enterprise Development, 15(2): 405-418.

Rodrigues, R., Dinis, A., Pao, A., Ferreira, J. J. \& Raposo, M. (2012). The Effect of an Entrepreneurial Training Programme on Entrepreneurial Traits and Intention of Secondary Students. 10.5772/35302.

Saleem, I., \& Anwar, I. (2018). Effect of Entrepreneurial Education on Entrepreneurial Intention of Indian Students. International Journal of Research, April.

Shane, S., \& Venkataraman, S. (2000). The Promise of Entrepreneurship as a Field of Research. Academy of Management Review, 25(1), 217. doi:10.2307/259271

Sharaf, A., El-Gharbawy, A., \& Ragheb, M. A. (2018). Factors That Influence Entrepreneurial Intention within University Students in Egypt. Journal, 5, 4881. https://doi.org/10.4236/oalib.1104881

Šrola, Davor. (2020). Determinants of entrepreneurial intentionsOdrednice poduzetničkih namjera: empirical evidence from Croatian perspectiveempirijski dokazi iz hrvatske perspektive. Zbornik Veleučilišta u Rijeci. 8. 169-187. 10.31784/zvr.8.1.17.

Souitaris, V., Zerbinati, S., Al-Laham, A. (2007). Do Entrepreneurship Programmes Raise Entrepreneurial Intention of Science and Engineering Students? The Effect of Learning, Inspiration and Resources. Journal of Business Venturing 22(4), 566-591

Srirejeki, K., \& Faturokhman, A. (2020). an Experimental Study on the Effectiveness of Mind-Mapping. August.

Viana, A. B. N., Carvalho, L. C., \& Cândido, R. B. (2019). Entrepreneurial Intentions of Management Students. March 2020, 1-17. https://doi.org/10.4018/978-1-5225-7675-4.ch001

Williams, N., \& Huggins, R. (2013). Supporting entrepreneurship in deprived communities: A vision too far? Journal of Small Business and Enterprise Development, 20. https://doi.org/10.1108/14626001311298466

Wright, B. Clarysse, P. Mustar, A. \& Lockett (2007). Academic Entrepreneurship in Europe . Cheltenham: Edward Elgar 2007. 228 pp., ISBN: 978184542648 4. International Journal of Entrepreneurial Behavior \& Research, 14, 63-65. https://doi.org/10.1108/13552550810852848

Yaghoubi-Farani, A., Karimi, S. \& Motaghed, M. (2017) The Role of Entrepreneurial Knowledge as a Competence in Shaping Iranian Students' Career Intentions to Start a New Digital Business. European Journal of Training and Development, 41, 83-100. https://doi.org/10.1108/EJTD-07-2016-0054

Zelienková, A., \& Kožárová, Z. (2019). Effect of entrepreneurial education on development of entrepreneurial competencies. July 2020, 216-225. https://doi.org/10.5817/cz.muni.p210-9488-201923 